\title{
Increase on Strengths of Hot Weather Concrete by Self-Curing of Wet Porous Aggregate
}

\author{
Sampebulu', V.1
}

\begin{abstract}
The compressive and tensile strengths of concrete made in hot weather condition decreased due to loss of mixing water caused by high evaporation. One method to overcome the problem is the use of saturated fly ash aggregate. The water content in fly ash aggregate can flow out to the hardened cement paste to continue the hydration process. This "self-curing" mechanism could produce more hydration around the surface of fly ash aggregate which subsequently increases concrete strength. Experimental study has been conducted in temperature of $20^{\circ}$ to $40^{\circ}$ with humidity of $70 \%$ for dry curing, water curing, and nearly $100 \%$ for fog curing. Effect of self-curing could be justified as the strengths of concrete using fly ash aggregates is higher than concrete using fly ash aggregates covered with silane agent, and crushed stone aggregates. Even in high temperature, the self-curing could increase the strengths of concrete due to bond strength around the surface of each fly ash aggregates.
\end{abstract}

Keywords: Bond strength, fly ash aggregate, hot weather concrete, self-curing, wet porous aggregate.

\section{Introduction}

Water or moisture content in hardened concrete affects the concrete design, especially in hot-humid climate such as in tropical countries. In hot temperatures, parts of mixing water would escape due to the natural process, such as evaporation, bleeding, and gel production due to unsatisfactory hydration which takes place during mixing of concrete, in fresh concrete and hardened concrete. This phenomenon would result in decrease of concrete strength. If all mixing water could totally hydrate with cement, the quality and strength of concrete will be better even under hot temperature. However, the presence of water or moist to continue the hydration process in hardened concrete is still required. To achieve this, Matsufuji, et al [1] sealed concrete with plastic to prevent the water to escape, but this method would probably be difficult to be applied in actual operation. An alternative way is needed to cope with this difficulty.

A phenomenon of water absorbed by porous aggregate, which then moving out into the hardened cement paste when concrete is already dry, could continuously present moisture in hardened concrete without treatment on the concrete surface.

\footnotetext{
${ }^{1}$ Laboratory of Building Material, Construction and Structure, Faculty of Engineering, Hasanuddin University, INDONESIA

Email: vicsam_ars@yahoo.com; vicsam@indosat.net.id

Note: Discussion is expected before November, $1^{\text {st }} 2012$, and will be published in the "Civil Engineering Dimension" volume 15, number 1, March 2013.
}

Received 20 December 2010; revised 14 July 2012; accepted 27 August 2012
During the process of the movement of water, the whole body will become damp; and because of high humidity of air, the rate of drying is low. This situation would support a continuous wet curing within the body of concrete. This phenomenon is called "selfcuring". The existence of the self-curing is firstly introduced by Matsufuji [2]. In his research, Matsufuji [2] found out that self-curing process would be clearer and can be detected under high temperature and humidity. Therefore, a better quality in terms of strength and drying shrinkage could be produced in hot humid climate [3].

This report studied the self-curing effect on strengths. Artificial lightweight aggregate, in this case fly ash having porous structure, was used.

\section{Mechanism of Self-curing}

Porous aggregate used in concrete is generally linked to poor quality of the concrete. However, when used in wet condition, the aggregate can provide favourrable effects on the concrete due to the water absorbed by the aggregate released slowly into the cement paste which has already hardened; thereby continuing the hydration process [4]. Because of that, improvements in concrete qualities such as increase in strengths and decrease in drying shrinkage will be obtained.

The water movement is caused by the humidity gradient between the aggregate that is high and the cement paste that is low. Since the hydrating reaction which inevitably absorbed water while the concrete is in the fresh and hardened states, the free 
water (mixing water) will decrease. Some remaining water does not have sufficient time to hydrate with cement, and the un-hydrated cement immediately covered with solid surface of hydrated cement. This is known as "self-desiccation". This desiccation will occur rapidly in high temperature. As a consequence, the relative humidity attains to the equilibrium condition.

As the paste filled with water again, the interrupted hydration process would resume and continue for relatively long time. This would create much more hydration products than in case no moisture or water moves to the paste. Thus, with wet porous aggregate, the absorbed water allows wet curing within the body of concrete to continue, taking part in hydration. The mechanism of the self-curing is shown in Figure 1. The term "self-curing" will distinguish this curing from another type of curing process that is almost similar, i.e. autogenous curing as described by Neville [5].

The difference between the two types is in the way of water supply and temperature requires to continue the curing. In self-curing, water comes from the aggregate, thus curing can take place in high and low temperature environment, while in the autogenous curing, curing is in adiabatic condition, utilizing heat generated by the hydration of cement's pure compounds. A specimen is sealed in a plastic bag after mixing and then placed in a polyurethane container for 46 hours. It is expected that the water to function in water curing comes from the free water already escaped as vapour around the container, and from water still existed within the body of specimen.

\section{Methodology}

To prove the presence of self-curing and its effect on strengths, several procedures, materials and mix proportions were attempted for use in this case.

\section{Materials and Mix Proportions}

All mixes used the same materials of cement and fine aggregate. Ordinary Portland cement and river sand was used. Two types of coarse aggregate were used, i.e. artificial lightweight fly ash (FA) and crushed stone. In this experiment, FA aggregate was used because unlike natural porous aggregate, has more homogeneous pores.

Fly ash is produced by combustion of pulverized coal in thermal power plants. As large quantities of the fly ash remain unutilized in most countries, attempts have been made to use fly ash for making lightweight aggregate. In a typical manufacturing process, the fly ash is moistened, made into pellets and sintered in a rotary kiln, shaft kiln, or a travelling grate at temperatures in the range 1000 to
(1) Fresh period

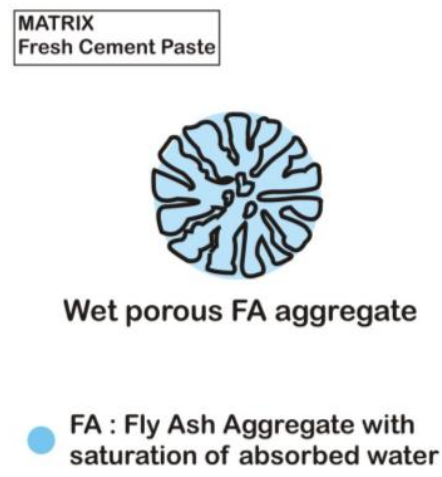

STATE 1:

The same humidity condition between FA aggregate and fresh cement paste, no movement of absorbed water
2) self-curing process

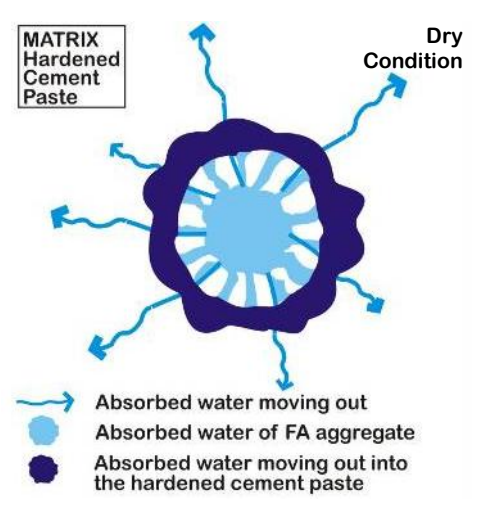

STATE 2:

The different humidity condition between FA aggregate and hardened cement paste (dry condition), absorbed water in FA aggregate is moving out into the hardened cement paste to continue hydration process around the surface of aggregate
(3) The process ended

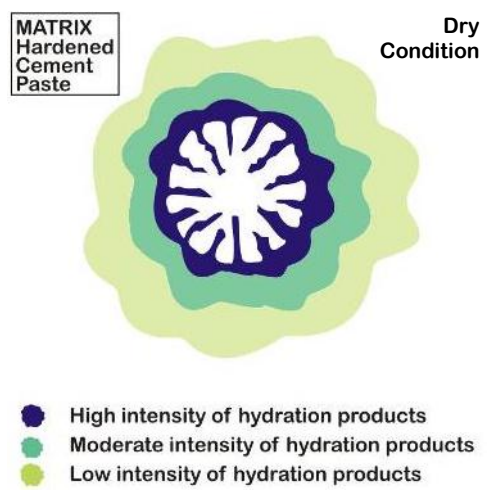

STATE 3:

The process of water moving out and hydration stopped, the high density of hydration products near the surface creates the layer that has higher bonding between hardened cement paste and the surface of FA aggregate, which is called as bond strength.

Figure 1. The Mechanism of Self-Curing 
$1200^{\circ} \mathrm{C}$ [6]. The size ranges from five to $15 \mathrm{~mm}$ in diameter. Fly ash aggregate is a porous aggregate.

Two types of FA aggregate were used in this experiment. First type was FA aggregate as wet porous aggregate which holds much water. Second type was of the same FA aggregate but immersed into a silane agent before mixing was done. As silane is a type of waterproofing material, initially absorbed water in the silane-immersed aggregate, would not move out or no water movement between the aggregate and the cement paste. This aggregate type is called Silane Fly Ash (SFA) aggregate.

Physical characteristics of all types of aggregates used and mix proportions are presented in Table 1 and 2 respectively. As shown in Table 1, the FA aggregate has a high absorptive capacity compared with other types.
Generally, as shown in Figure 2, this FA aggregate absorbed water even after several days, and attained to equilibrium in one month [7]. But in this experiment, FA aggregate at time of mixing did not quite attain to the saturation point.

Mix proportions of concrete and mortar are shown in Table 2. For the purpose of this experiment, proportions of water (W) and coarse aggregate $(\mathrm{G})$ were made constant so as to allow the effect of selfcuring in relation with various water-cement ratios. Chemical admixtures of air-entrained agent (vinsol type) and water-reducing agent (high flood type) were also added into the mixes. The reason of adding water-reducing agent (high flood type) to concrete using lower W/C ratio (W/C 35\%) is to improve the workability of fresh concrete and easy to cast into the molds or formworks, see also Table 3.

Table 1. Physical Characteristic of Aggregate Used

\begin{tabular}{|c|c|c|c|c|c|c|c|}
\hline \multirow{2}{*}{ Aggregate } & \multicolumn{2}{|c|}{ Spesific Gravity } & \multirow{2}{*}{ Size (mm) } & \multirow{2}{*}{$\begin{array}{l}\text { Absorbed } \\
\text { Water (\%) }\end{array}$} & \multirow{2}{*}{$\begin{array}{l}\text { Unit Weight } \\
\mathrm{Kg} / \mathrm{m}^{3}\end{array}$} & \multirow{2}{*}{$\begin{array}{c}\text { Absolute } \\
\text { Volume (\%) }\end{array}$} & \multirow{2}{*}{$\begin{array}{l}\text { Fineness } \\
\text { Modulus }\end{array}$} \\
\hline & Dry & Saturation & & & & & \\
\hline FA & 1.35 & 1.59 & 15.00 & 17.80 & 0.87 & 64.40 & 6.40 \\
\hline Silane FA & 1.36 & 1.39 & 15.00 & 2.22 & 0.87 & 64.40 & 6.40 \\
\hline Crushed Stone & 2.88 & 2.99 & 20.00 & 0.81 & 1.66 & 58.60 & 6.60 \\
\hline River Sand & 2.51 & 2.56 & 2.50 & 1.83 & 1.64 & 65.20 & 2.50 \\
\hline
\end{tabular}

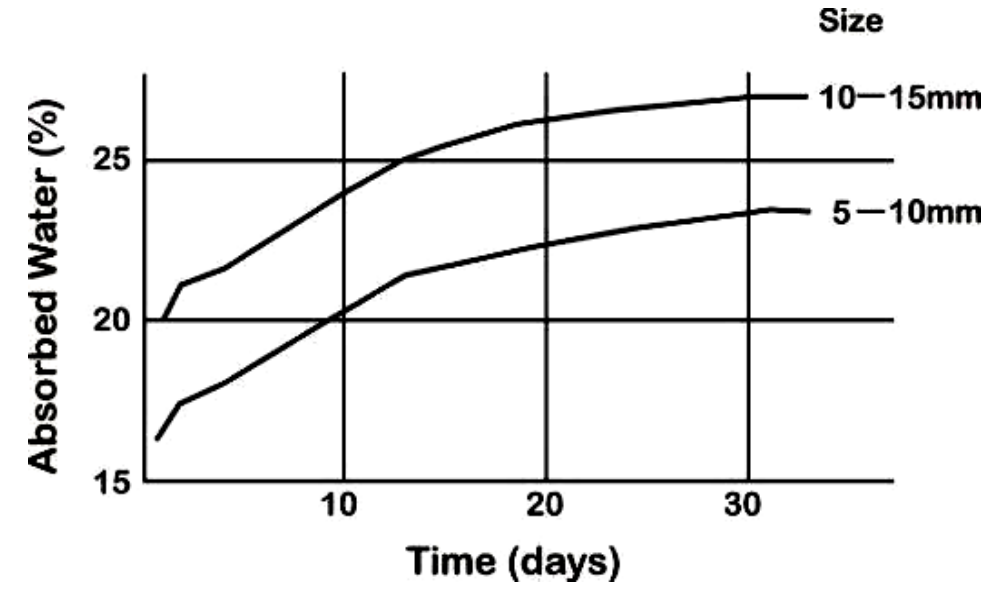

Figure 2. Increase of Water Absorbed by Fly Ash Aggregate with Increase in Time [7]

Table 2. Mix Proportions

\begin{tabular}{|c|c|c|c|c|c|c|c|c|}
\hline \multirow{2}{*}{ W/C (\%) } & \multirow{2}{*}{ Slump (cm) } & \multicolumn{4}{|c|}{ Proportion (1/m³) } & \multirow{2}{*}{ Air Content } & \multirow{2}{*}{ Sand Ratio s/a } & \multirow{2}{*}{$\mathrm{AE}(\% . \mathrm{C})$} \\
\hline & & $\mathrm{C}$ & $\mathrm{W}$ & $\mathrm{S}$ & $\mathrm{G}$ & & & \\
\hline 35 & & 163 & & 257 & & & 0.42 & \\
\hline 45 & 18 & 126 & 180 & 294 & 360 & 4.0 & 0.45 & 0.03 \\
\hline 55 & & 104 & & 316 & & & 0.47 & \\
\hline
\end{tabular}

\section{Note:}

$\mathrm{C} \quad=$ Cement, $\mathrm{W}=$ Water, $\mathrm{S}=$ Sand , and $\mathrm{G}=$ Aggregate of Crushstone and Fly Ash

$\mathrm{s} / \mathrm{a}=\mathrm{Sand} /$ Total of Sand + Aggregate (crushed stone and fly ash)

$\mathrm{AE}=$ Air-Entrained agent (vinsol type) in \% of Cement (C)

$\mathrm{W} / \mathrm{C}=$ Water/ Cement ratio in $\%$ 


\section{Method of Experiments}

The methods used are shown in Table 3 for strength test. Japanese Industrial Standards of JIS A 1108 [8] method was applied for compressive strength test and purely-pulled method for tensile strength test.

\section{Result and Discussion}

Properties of fresh concrete are shown in Table 4. The slump test result was about $18 \mathrm{~cm}$ for concrete using FA and about $21 \mathrm{~cm}$ for concrete using crushed stone aggregate. For W/C 35\%, the same slump of

Table 3. Outline of Experiment for Strength Test

\begin{tabular}{|c|c|c|c|c|c|c|}
\hline \multicolumn{2}{|c|}{ Code of Specimen } & \multirow{2}{*}{$\begin{array}{l}\text { Temperature of } \\
\text { Material }\left({ }^{\circ} \mathrm{C}\right)\end{array}$} & \multirow{2}{*}{$\begin{array}{l}\text { Curing Condition and } \\
\text { Method }\end{array}$} & \multirow{2}{*}{$\begin{array}{l}\text { Size of Specimen } \\
(\mathrm{cm})\end{array}$} & \multicolumn{2}{|c|}{ Chemical admixture (\%.C) } \\
\hline Code & $\mathrm{W} / \mathrm{C}(\%)$ & & & & $\mathrm{AE}$ & Water Reducing \\
\hline & 35 & & Standard Room & compressive & & 0.4 \\
\hline FA & 45 & & & $\varnothing 10 \times 20$ & & - \\
\hline & 55 & normal & $20^{\circ} \mathrm{C}$ & & & 04 \\
\hline SFA & 35 & & Hot Room & Tensile & 0.03 & 0.4 \\
\hline $\mathrm{CA}$ & 35 & & & $\varnothing 7.5 \times 15$ & & 0.4 \\
\hline
\end{tabular}

Note:

FA- Fly Ash aggregate, SFA-Silane Fly Ash Aggregate

CA- Crushed Stone Aggregate, RH-Relative Humidity

Table 4. Result of Fresh Concrete

\begin{tabular}{cccc}
\hline Code of Specimen & Slump $(\mathrm{cm})$ & Air Content $(\%)$ & Unit Weight $\left(\mathrm{kg} / \mathrm{m}^{3}\right)$ \\
\hline FA-45 & 19.8 & 7.6 & 1.831 \\
FA-55 & 17.3 & 7.2 & 1.826 \\
SFA-35 & 17.5 & 7.2 & 1.816 \\
CA-35 & 20.3 & $3.1(4.3)$ & 2.417 \\
\hline
\end{tabular}

Table 5. Results of Hardened Concrete, Strength Test

\begin{tabular}{|c|c|c|c|c|c|c|c|c|}
\hline \multirow{2}{*}{$\begin{array}{c}\text { Code of } \\
\text { Specimen }\end{array}$} & \multicolumn{2}{|c|}{ Curing } & \multicolumn{4}{|c|}{ Compressive Strength (MPa) } & \multirow{2}{*}{$\begin{array}{c}28 \text { days Static } \\
\text { Modulus of Elasticity } \\
\left(\mathrm{x} 10^{4} \mathrm{MPa}\right)\end{array}$} & \multirow{2}{*}{$\begin{array}{c}28 \text { days Static } \\
\text { Tensile Strength } \\
\text { (MPa) }\end{array}$} \\
\hline & Condition & Method & 7 days & 16 days & 28 days & 91 days & & \\
\hline \multirow{4}{*}{ FA-35 } & \multirow{2}{*}{$20^{\circ} \mathrm{C}$} & Water & 34.8 & 39.3 & 41.7 & 46.8 & 2.06 & - \\
\hline & & Dry & 35.9 & 40.1 & 46.3 & 49.7 & 2.01 & 3.35 \\
\hline & \multirow{2}{*}{$40^{\circ} \mathrm{C}$} & Fog & 40.1 & 44.3 & 45.1 & 49.2 & 2.13 & - \\
\hline & & Dry & 38.9 & 43.2 & 46.1 & 49.0 & 1.98 & 3.35 \\
\hline \multirow{4}{*}{ FA-45 } & \multirow{2}{*}{$20^{\circ} \mathrm{C}$} & Water & 23.5 & 30.7 & 35.5 & 37.1 & 1.78 & - \\
\hline & & Dry & 25.8 & 34.0 & 37.3 & 38.1 & 1.63 & 2.81 \\
\hline & \multirow{2}{*}{$40^{\circ} \mathrm{C}$} & Fog & 27.2 & 35.6 & 37.5 & 40.2 & 1.86 & - \\
\hline & & Dry & 27.6 & 34.5 & 36.0 & 37.5 & 1.65 & 2.69 \\
\hline \multirow{4}{*}{ FA-55 } & \multirow{2}{*}{$20^{\circ} \mathrm{C}$} & Water & 18.7 & 24.3 & 27.7 & 30.9 & 1.90 & - \\
\hline & & Dry & 19.6 & 25.1 & 27.6 & 30.0 & 1.57 & 2.15 \\
\hline & \multirow{2}{*}{$40^{\circ} \mathrm{C}$} & Fog & 22.8 & 25.8 & 28.3 & 33.0 & 1.87 & - \\
\hline & & Dry & 21.8 & 24.0 & 26.8 & 29.5 & 1.53 & 2.33 \\
\hline \multirow{4}{*}{ SFA-35 } & \multirow{2}{*}{$20^{\circ} \mathrm{C}$} & Water & 35.2 & 40.4 & 42.1 & 46.2 & 2.12 & - \\
\hline & & Dry & 38.2 & 42.2 & 42.4 & 44.2 & 1.89 & 3.13 \\
\hline & \multirow{2}{*}{$40^{\circ} \mathrm{C}$} & Fog & 38.2 & 41.3 & 44.8 & 44.7 & 2.20 & - \\
\hline & & Dry & 34.5 & 39.2 & 43.0 & 43.2 & 1.82 & 2.79 \\
\hline \multirow{4}{*}{ CA-35 } & \multirow{2}{*}{$20^{\circ} \mathrm{C}$} & Water & 37.8 & 42.3 & 46.5 & 52.3 & 3.31 & - \\
\hline & & Dry & 38.8 & 44.0 & 47.2 & 45.3 & 3.28 & 2.35 \\
\hline & \multirow{2}{*}{$40^{\circ} \mathrm{C}$} & Fog & 41.0 & 44.3 & 48.7 & 52.4 & 3.67 & - \\
\hline & & Dry & 39.7 & 41.1 & 44.3 & 44.0 & 3.07 & 2.20 \\
\hline
\end{tabular}

Note:

FA-35, FA-45, and FA-55, Fly Ash Aggregate concrete using W/C = 35\%, 45\% and 55\% respectively

SFA-35, Fly Ash Aggregate concrete covered with silane agent using W/C = 35\%

CA-35, Crushed Stone Aggregate concrete using W/C = 35\% 
about $21 \mathrm{~cm}$ was obtained for fresh concrete with FA aggregate (FA-35) and crushed stone aggregate (CA35).

In general, FA aggregate concrete is characterized by much air content and lighter unit weight (Table 4). Since FA aggregate is usually not saturated completely with water thus with a great deal of air still remaining in the aggregate, the use of an ordinary pressure method for measuring the air content of fresh FA aggregate concrete is rather difficult. In this study, the method of JIS A 1116 [8] has been used to measure the air content and unit weight of fresh concrete.

\section{Strengths}

The characteristics of strengths to be discussed consist of compressive and tensile strengths, and static modulus of elasticity as shown in Table 5.

\section{Compressive Strength}

The effect of self-curing in FA-35, FA-45, and FA-55 became more significant at the age of 91 days as compared with SFA and CA concrete for the same age. In dry curing at both $20^{\circ} \mathrm{C}$ and $40^{\circ} \mathrm{C}$ curing conditions, the strength of FA concrete was 3-4 MPa higher than that of SFA concrete. The strength of FA concrete continuously increased from 28 to 91 days but the opposite results found for SFA and CA concrete, see Figure 3.

Since the W/C ratio is constant, it is expected that only one factor causes the increase, namely, the selfcuring in which the absorbed water of FA aggregate moves into the hardened cement paste and then the hydration process once interrupted would resume to go on.

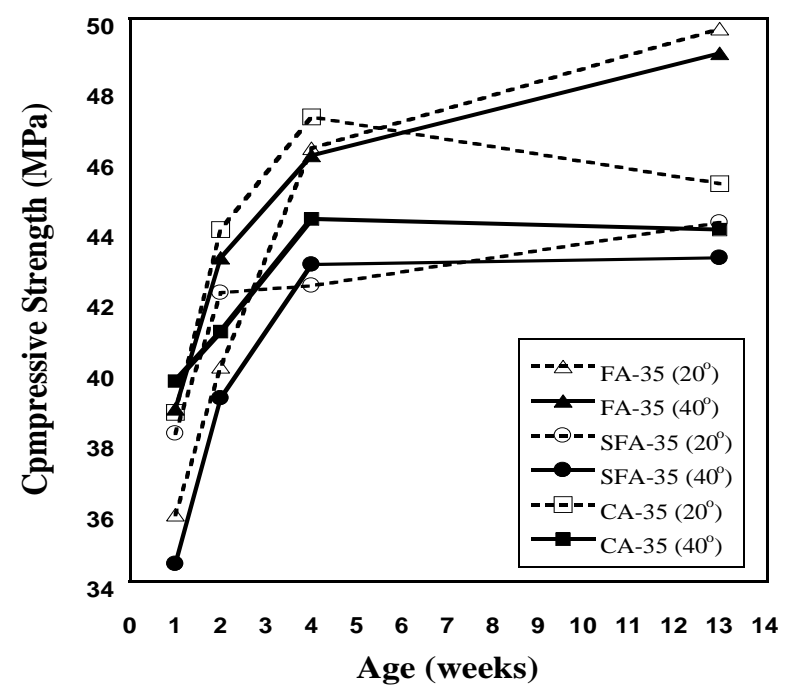

Figure 3. Effect of Curing Temperature on the Compressive Strength of FA-35, SFA-35, and CA-35. Dry Curing, $\mathrm{W} / \mathrm{C}=35 \%$.
The clearest evidence of self-curing effect is that the later-age strength of FA concrete is higher than crushed stone aggregate concrete. This is contrary to the visual case in which an ordinary concrete is stronger than all types of a lightweight concrete. This usual case appeared in water and fog curing at both $20^{\circ} \mathrm{C}$ and $40^{\circ} \mathrm{C}$ in which the CA concrete had 52 $\mathrm{MPa}$ at 91 days (Table 5) that was the highest strength in this experiment. This value is lower by about 7-8 MPa for that in dry curing.

Table 6 shows the percentage difference in compressive strength from the dry curing to those from the water curing $\left(20^{\circ} \mathrm{C}\right.$, Standard Room) and fog curing $\left(40^{\circ} \mathrm{C}\right.$, Hot Room), see Table 3 . Values of crushed stone aggregate concrete in $40^{\circ} \mathrm{C}$ curing decreased with time increased. At least two factors shape and absorbed water of aggregate are responsible for that decrease. During the fresh state period when a process of bleeding or sedimentation is taking place, pockets (voids) are formed easily underneath an angular shape of crushed aggregate [9]. The ratio of $\mathrm{W} / \mathrm{C} 35 \%$ and less than $1 \%$ of absorbed water of the aggregate are small values. While the bleeding is going on, the water is trapped within the formed pockets between aggregate and matrix. After the bleeding finished and the concrete hardened, the pockets become dry when curing goes on in dry condition. As a consequence, the pockets will become a cause of crack as they consist of just air and soft parts. Moreover, the edges of angular aggregate produces a concentration stress when concrete is subjected to load forces and this then increases the possibility of cracks occurring easily around the pockets.

The effect of W/C ratio on strength is clearly seen in Table 6. For both $20^{\circ} \mathrm{C}$ and $40^{\circ} \mathrm{C}$, the smaller the $\mathrm{W} / \mathrm{C}$ ratio the higher the percentage difference of comprehensive strength was found. The density of concrete thus seems to have relation with this. The density becomes heavier as the absorbed water moves from FA aggregate. The water continues to create more hydration products around the aggregate pieces. Therefore, this improves bond strength between the aggregate and the cement paste.

The development of strength in dry curing is greater for the concrete made with FA aggregate. The different strength ratios of dry curing to the water curing $\left(20^{\circ} \mathrm{C}\right.$, Standard Room) and fog curing $\left(40^{\circ} \mathrm{C}\right.$, Hot Room) are shown from Figure 4 and 5 according to the calculation results in Table 6 .

Even at $40^{\circ} \mathrm{C}$ curing temperature, the strength of FA concrete is higher than that of CA concrete (Figure 4). Various water-cement ratios of FA concrete also resulted in various strengths and particularly a 
smaller W/C ratio provided a greater strength for dry curing at both $20^{\circ} \mathrm{C}$ and $40^{\circ} \mathrm{C}$ (Figure 5).

\section{Tensile Strength}

Tensile strengths of each type of concrete are shown in Table 5. To prove the self-curing effects, no testing was done for specimens by water and fog curing. Various degrees of tensile strength are found for the FA concrete specimens classified in four W/C ratios.
The strengths for W/C 35\% are the highest among them. Apparently low total water gives better tensile strengths. Based on purely visual observation of the broken surface of specimens already tested, FA aggregate were cut in two parts (Figure 6). This indicates that the bond strength around the aggregate worked favourably. The remaining bond layers are seen around the broken FA aggregates. The remarkable indication is that all the apparent aggregates had broken in FA concrete of W/C 35\%.

Table 6. Percentage Difference in Compressive Strength of Dry Curing to the Strength of Water Curing $\left(20^{\circ} \mathrm{C}\right.$, Standard Room) and Fog Curing $\left(40^{\circ} \mathrm{C}\right.$, Hot Room)

\begin{tabular}{|c|c|c|c|c|c|c|}
\hline \multirow{2}{*}{ Code of Specimen } & \multirow{2}{*}{ Curing Condition } & \multicolumn{2}{|l|}{ Percentage } & \multicolumn{3}{|c|}{ Percentage Difference } \\
\hline & & fdry/Fwet & 7 Days & 14 Days & 28 Days & 91 Days \\
\hline \multirow{2}{*}{ FA-35 } & $20^{\circ} \mathrm{C}$ & fdry/fwater & 3.2 & 2.0 & 11.0 & 6.2 \\
\hline & $40^{\circ} \mathrm{C}$ & fdry/ffog & -3.0 & -2.5 & 2.2 & -0.4 \\
\hline \multirow{2}{*}{ FA-45 } & $20^{\circ} \mathrm{C}$ & fdry/fwater & 9.8 & 10.7 & 5.1 & 2.7 \\
\hline & $40^{\circ} \mathrm{C}$ & fdry/ffog & 1.5 & -3.1 & -4.0 & -6.7 \\
\hline \multirow{2}{*}{ FA-55 } & $20^{\circ} \mathrm{C}$ & fdry/fwater & 4.8 & 3.3 & -4.0 & -3.0 \\
\hline & $40^{\circ} \mathrm{C}$ & fdry/ffog & -4.4 & -7.0 & -5.3 & -10.6 \\
\hline \multirow{2}{*}{ SFA-35 } & $20^{\circ} \mathrm{C}$ & fdry/fwater & 8.5 & 4.5 & 0.7 & -4.3 \\
\hline & $40^{\circ} \mathrm{C}$ & fdry/ffog & -9.7 & -5.1 & -4.0 & -3.4 \\
\hline \multirow{2}{*}{ CA-35 } & $20^{\circ} \mathrm{C}$ & fdry/fwater & 2.6 & 4.0 & 1.5 & -13.4 \\
\hline & $40^{\circ} \mathrm{C}$ & fdry/ffog & -3.2 & -7.2 & -9.0 & -16.0 \\
\hline
\end{tabular}

Note:

fdry $=$ concerete strength for dry curing in Standard and Hot Room

fwater $=$ concrete strength for water curing $\left(20^{\circ} \mathrm{C}\right.$, Standard Room $)$

ffog $=$ concrete strength for fog curing $\left(40^{\circ} \mathrm{C}\right.$, Hot Room $)$

Fwet $=$ representation of concrete strength for water curing $\left(20^{\circ} \mathrm{C}\right.$, Standard Room $)$ and fog curing $\left(40^{\circ} \mathrm{C}\right.$, Hot Room $)$

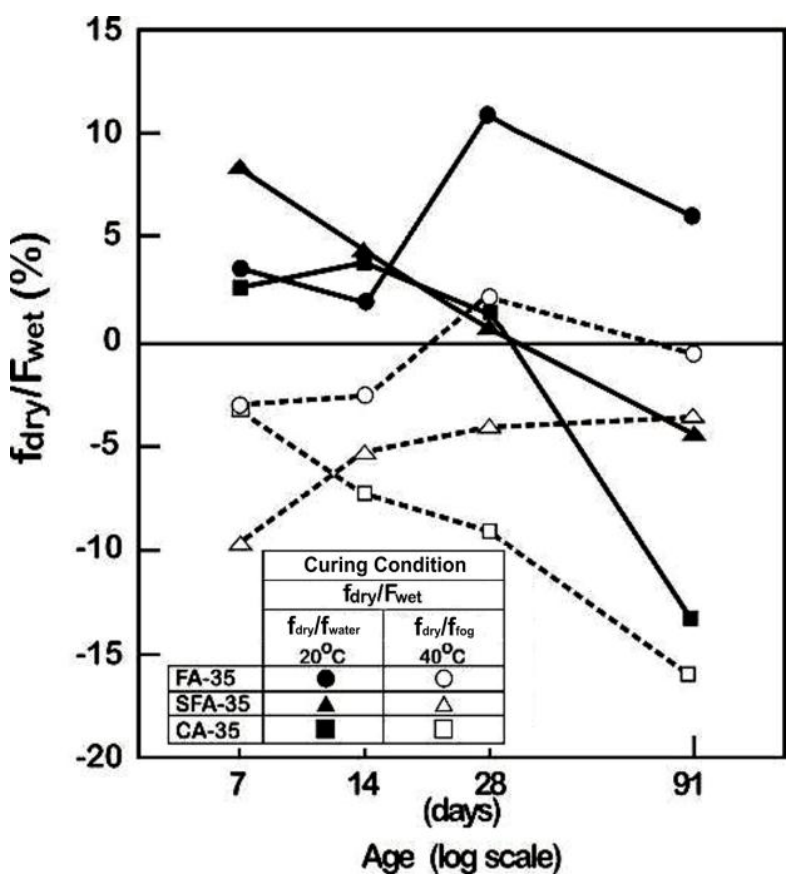

Figure 4. Development of Compressive Strength of FA-35, SFA-35, and CA-35 in $20^{\circ} \mathrm{C}$ and $40^{\circ} \mathrm{C}$ of Dry Curing Compared with Water Curing $\left(20^{\circ} \mathrm{C}\right.$, Standard Room) and Fog Curing $\left(40^{\circ} \mathrm{C}\right.$, Hot Room).

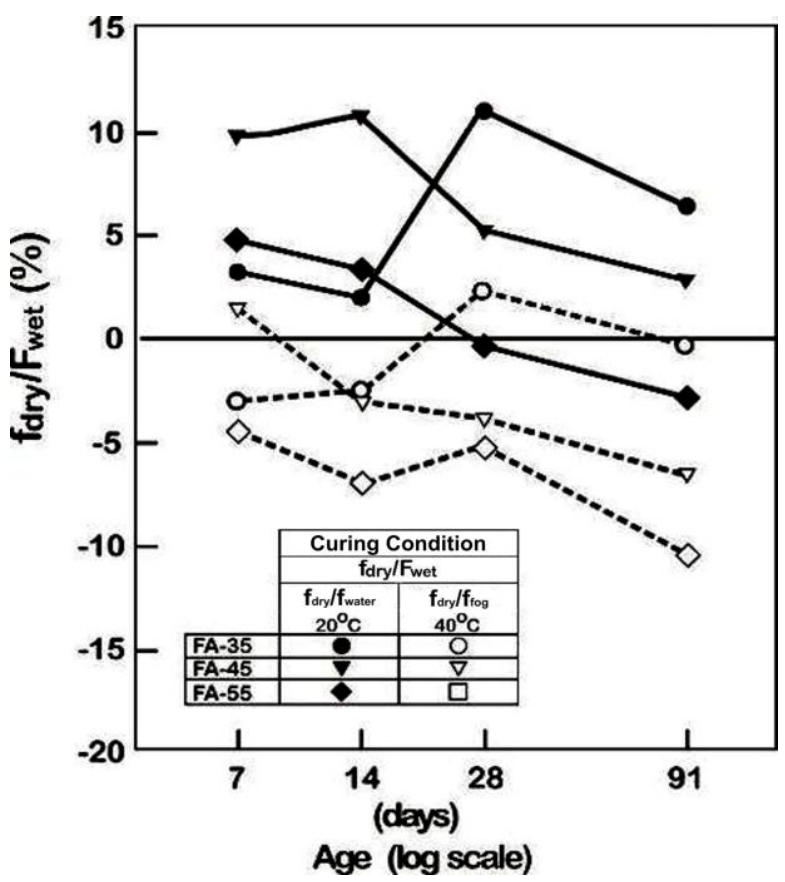

Figure 5. Development of Compressive Strength of FA-35, FA-45, and FA-55 in $20^{\circ} \mathrm{C}$ and $40^{\circ} \mathrm{C}$ of Dry Curing Compared With Water Curing $\left(20^{\circ} \mathrm{C}\right.$, Standard Room) and Fog Curing $\left(40^{\circ} \mathrm{C}\right.$, Hot Room) 

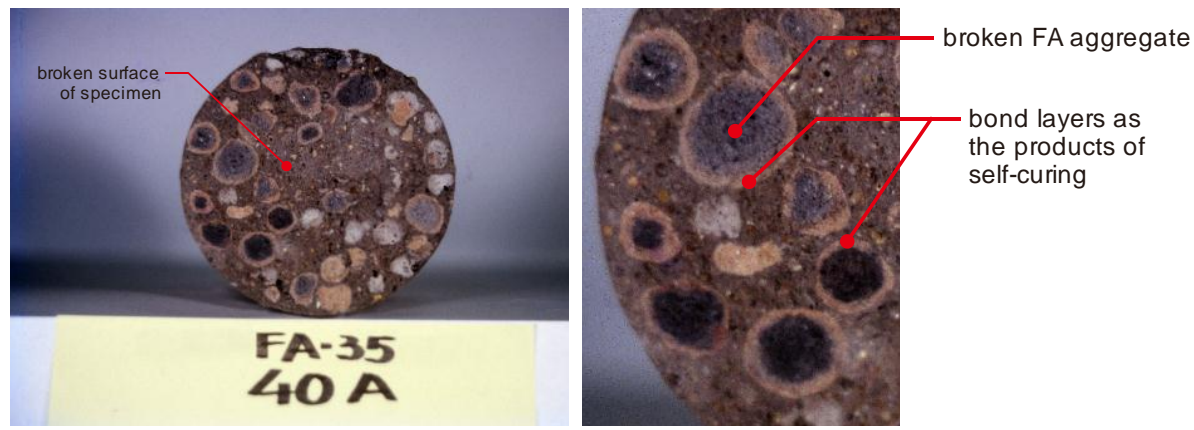

Purely-Pulled Method
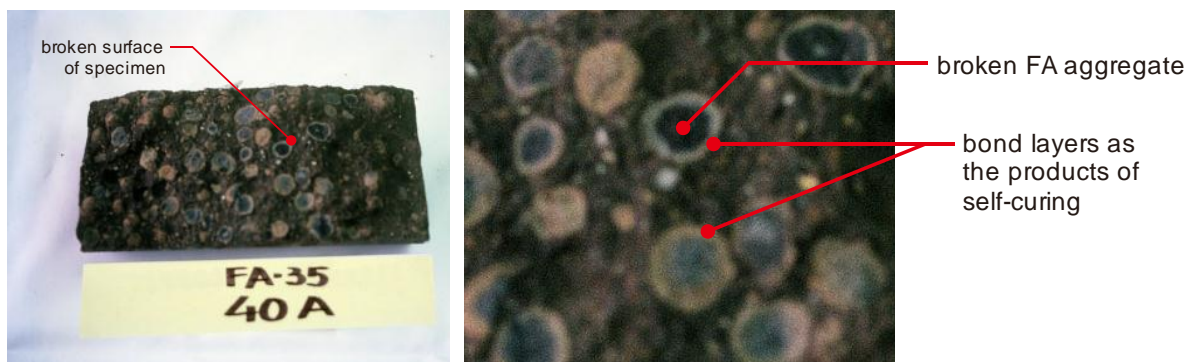

Splittina Test Method

Figure 6. Broken Surface of Specimens of FA Concrete W/C 35\% with $40^{\circ} \mathrm{C}$ Dry Curing

It is obvious that the water absorbed in FA aggregate has already moved out into the hardened cement paste to maintain the hydration process. And the progress of the process is recognized much more in the cement paste around the FA aggregate (Figure 1). The result of the process, therefore, improves the bond strength. This is clearly proven by the case of W/C 35\% in which the tensile strength of FA concrete is the highest compared with the concrete of other W/C ratios.

No effect of self-curing can be seen in SFA concrete for which the tensile strength by curing at $40^{\circ} \mathrm{C}$ is lower than that at $20^{\circ} \mathrm{C}$ due to the self-desiccation occurring more rapidly under high temperature (Table 5). Because no surplus water supplies the selfdesiccated water, use of SFA aggregate weakens the tensile strength. A comparison between compressive and tensile strength at the age of 28 days is shown in Figure 7.

Tensile strength of FA concrete ranges from 1/12 to $1 / 16$ of its compressive strength. No different value is found between $20^{\circ} \mathrm{C}$ and $40^{\circ} \mathrm{C}$ curing conditions for FA-35 but the value varied for FA-45 and FA-55 in which the value was higher for $40^{\circ} \mathrm{C}$. A multiple reaction of hydration takes place when ambient temperature is high [10]. Because of self-curing, the chemical reaction taking place between the aggregate and cement paste increases their bond strength.

On the contrary, the value is lower for $40^{\circ} \mathrm{C}$ curing condition for SFA and CA concrete. Because such aggregate has neither exit nor enough water, the self-curing does not work in both cases. In addition, $40^{\circ} \mathrm{C}$ of air temperature causes much rapid water evaporating from the concrete. These conditions, high temperature and lack of water in the body, dry the concretes out and as a result their bond strength does not build up.

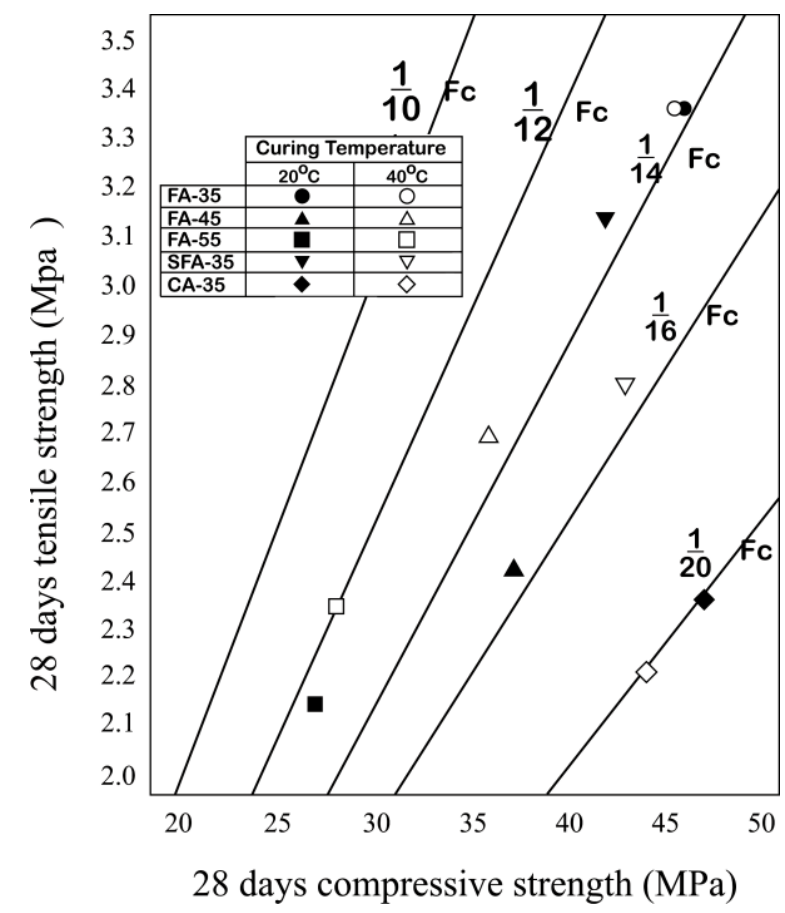

Figure 7. Relation Between Compressive and Tensile Strength at the age of 28 Days 
In Figure 7, the tensile strength of the CA concrete is about $1 / 20$ of its compressive strength. This belongs to a low value range comparing with the values of FA and SFA concrete. Effect of bond weave around the irregular surface of the crushed stone aggregate is responsible for the low value. Because the aggregate shape is irregular, bleeding water easily collects beneath the pieces of the aggregate [9]. If tensile force is given to such a zone under this circumstance, cracks develop initially in the zone before spreading to other zones in the concrete body.

There are two indications about the magnitude of bond strength between the aggregate and cement paste on the specimen that is broken off by a pulling force. Firstly, if the apparent pieces of the aggregate are broken with mortar matrix around them, this indicates that the bond is strong enough to its ultimate power to hold the aggregate. But, secondly, if the aggregates are not broken this means the bond is weak. By examining the broken surface of the specimens, the first indication appears on all the FA aggregates and the second on all the CA (crushed stone) aggregates and a half of SFA aggregates. The last case of SFA aggregates provides another theory that a globular shape and open pores appeared on aggregate surface are also the factors enhancing the bond strength.

\section{Modulus of Elasticity}

Modulus of elasticity to be determined by applying a static method was obtained from the 28 days strength. In all the concretes shown in Table 5, the elasticity resulted from dry curing is smaller than those from water and fog curing. There is a tendency in FA concrete that the elasticity decreases with increase in a ratio of water cement.

Comparing FA and SFA concrete under dry curing condition the elasticity of FA concrete is slightly high. Since the W/C ratio is the same, the only factor that may explain the difference is possible improvement of bond strength between aggregate and matrix through self-curing.

\section{Conclusion}

The existence of self-curing in concrete using fly ash aggregate as wet porous aggregate provides favourable effects on properties of concrete. Several conclusions are drawn as the significant effects of the self-curing.

In moderate and high ambient temperature, fly ash aggregate concrete provides higher compressive and tensile strengths compared with silane fly ash and crushed stone aggregate concrete. Particularly for tensile strength, the higher temperature gives a favourable effect as it contributes a better bond strength around the fly ash aggregate.

There is a tendency that high temperature accompanied by high relative humidity gives a favourable effect on properties of concrete if wet porous aggregate is used. Thus, it should be widely applied in making concrete in hot humid environment.

\section{References}

1. Matsufuji, Y., Ohkubo, T., Harada S and Sampebulu', V., A Study on strength of Concrete Mixed and Cast in High Temperature Ambience, Proceeding of the Japan Concrete Institute, 10(2), 1988, pp. 277-280.

2. Matsufuji, Y., Shigetoku, K., and Sampebulu', V., Properties of Open Pores Aggregate Concrete in Hot Weather, The Cement Association of Japan, 1986, pp.124-127.

3. Sampebulu', V., A Basic Study on the Properties of Hot Weather Concrete, Dissertation of Doctor's Degree, 1988, pp. 131-145.

4. Sampebulu', V., Pengaruh Cuaca Panas Terhadap Kualitas Beton, National Seminar of Indonesia, Makassar, 2001, The $5^{\text {th }}$ Paper.

5. Neville, A.M., Properties of Concrete, Pitman Books Limited, Third Edition, 1982, p. 572.

6. Mehta, P.K. and Monteiro, P.J.M., Concrete: Microstructure, Properties, and Materials, McGraw-Hill, Third Edition, 2006, p. 263.

7. Tomosawa, Y., A Study on the Fly Ash Aggregate as the Aggregates of Lightweight Concrete, Architectural Institute of Japan (AIJ), No.353, 1985, pp. 121-128.

8. Tomosawa, F., Shimizu, A., Abe, M., Imai, H., Maeda, K., Tamura, H., Morinaga, S., Okamura, K., Baba, A., Matsufuji, Y., and Watanabe, F., Quality Control and Inspection of Concrete, Japanese Architectural Standard Specification for Reinforced Concrete Work, JASS 5, Revised 1993 (English Version), Architectural Institute of Japan (AIJ), 1993, pp. 59 and pp. 127-128.

9. Sampebulu', V., Deleterious Water Effect on Reinforced Concrete Used in Building, Proceeding of International Seminar on Green Architecture and Environment: Towards Green Compact Cities, Makassar 2008, pp. 193-202.

10. Idron, G.M., Hydration of Portland Cement Paste at High Temperature under Atmospheric Pressure, Proceedings of the $5^{\text {th }}$ International Symposium on the Chemistry of Cement, Vol III, Tokyo, 1968, pp. 411-428. 